\title{
Analisis Program Pembangunan dan Pemberdayaan Kewilayahan di Kota Bandung
}

\section{Analysis of the Regional Development and Empowerment Program in Bandung City}

\author{
Siti Alia1, Joko Maulana ${ }^{2}$ \\ 1-2UIN Sunan Gunung Djati Bandung \\ Jl. Raya A.H. Nasution No. 105 Cibiru Kota Bandung, 40614 \\ *corresponding author E-mail: Aliaalya267@yahoo.com
}

Diterima: 20 November 2019 ; Direvisi: 4 Desember 2019 ; Disetujui: 4 Desember 2019

\begin{abstract}
ABSTRAK
Perbedaan hasil penyerapan anggaran PIPPK Di Kelurahan Cihapit dan Kelurahan Merdeka dapat dijadikan dasar berjalan dengan baiknya suatu program.Terjadinya perbedaan perbedaan penyerapan anggaran antara dua kelurahan antara kelurahan merdeka dan cihapit menjadi fondasi penulis melakukan analis akan inovasi program yang sedang berjalan saat ini, yaitu program PIPPK di kota Bandung. Metode penelitian menggunakan pendekatan kualitatif dan data diperoleh dengan studi kepustakaan dan studi lapangan. Hasil penelitian menunjukkan salah satu penyebab perbedaan penyerapan anggaran antara dua kelurahan tersebut terdapat pada kegiatan dan program yang dilakukan oleh kelurahan dan dukungan yang optimal dari pihak Aparatur dan Masyarakat, sehingga menghasilkan kelurahan Cihapit dengan dukungan aparatur dan desa dapat mengoptimalkan dana dari program PIPPK beda dengan kelurahan Merdeka di mana yaitu kurangnya partisipasi masyarakat dan juga masih kurangnya aparatur di kelurahan merdeka membuat sosialisasi kepada masyarakat menjadi kurang. mengemukakan saran Pemerintah Kota Bandung Perlu peninjauan ulang mengenai tambahan SDM ahli sebagai tenaga pendamping di Kelurahan khusus untuk menangani PIPPK agar hasilnya lebih maksimal mengingat dengan adanya PIPPK tentunya memberikan tambahan beban kerja bagi SDM yang ada di Kelurahan yang jumlah personilnya hanya 7 sampai 8 orang.
\end{abstract}

Kata Kunci: Analisis, Kebijakan Publik, Keberhasilan Program

\section{ABSTRACT}

The difference in the results of absorption of the PIPPK budget in Cihapit Kelurahan and Merdeka Kelurahan can be used as a basis for a good program. The difference in budget absorption differences between the two kelurahan between merdeka and cihapit kelurahan is the foundation for the writer to analyze the innovations of the current program, the PIPPK in the city of Bandung. The research method uses a qualitative approach and data obtained by library 
research and field studies. The results showed that one of the causes of the difference in budget absorption between the two villages was found in the activities and programs carried out by the kelurahan and optimal support from the apparatus and community so that producing Cihapit kelurahan with apparatus and village support could optimize funds from the PIPPK program in contrast to the kelurahan Merdeka, where there is a lack of community participation and also a lack of apparatus in the merdeka kelurahan, makes socialization to the community less. Put forward the suggestion of the Government of the City of Bandung Needs a review of the addition of expert human resources as a companion in a special Kelurahan to deal with PIPPK so that the results are more optimal given the existence of PIPPK certainly provides additional workload for HR in the Kelurahan with only 7 to 8 people.

Keywords: Analyst, Public Policy, Success of the program

\section{PENDAHULUAN}

PIPPK merupakan salah satu program unggulan dalam masa pemerintahan Walikota Ridwan Kamil dari sejak terpilih sampai menyelesaikan amanah sebagai Walikota beberapa waktu yang lalu, program PIPPK diharapkan dapat menggerakkan kembali keaktifan masyakarat dalam membangun wilayahnya masing sesuai dengan asas keterbukaan. Tiga bentuk inovasi utama pada kepemimpinan Ridwan Kamil yaitu Bandung Smart City, Program Inovasi Pembangunan, Pemberdayaan Kewilayahan (PIPPK) dan Penataan Pedagang Kaki Lima.

Melalui PIPPK yang senada pada tujuan Bandung Empowerment City, yaitu didalam PIPPK terdapat semangat kebersamaan, desentralisasi, dan mendorong kemampuan leadership aparatur. Sasaran dari PIPPK adalah terwujudnya komitmen dan konsistensi perencanaan serta pelaksanaan kegiatan pembangunan di Kelurahan yang diorientasikan pada pembangunan masyarakat setempat dengan pendekatan inovasi, desentralisasi dan kolaborasi dengan kebutuhan serta kemampuan masyarakat Kelurahan yang didukung sistem pendampingan, pengawasan dan pengendalian yang efektif (Ramdani \& Habibi, 2017a).

Berdasarkan wawancara pra observasi dengan Kabag Pemerintahan Umum Kota Bandung diketahui bahwa dari jumlah 30 kecamatan di Kota Bandung yang di dalamnya terdiri dari 151 kelurahan, sudah dilaksanakan 
secara serentak sejak tahun 2015, dimana pelaksanaannya yaitu 40\% untuk Infrastruktur, 20\% untuk Kebersihan, 20\% untuk sosial ekonomi, dan 20\% untuk pemberdayaan. Diantaranya ada beberapa kelurahan dan kecamatan yang berhasil sebagai kecamatan dan kelurahan terbaik dalam pelaksanaan PIPPK dan mendapatkan PIPPK awards dilihat dari indikator pencapaian realisasinya, diantaranya Kelurahanan Cipadung, Cimincrang, Nyengseret, Cihapit dan Dunguscariang, tetapi ada pula kecamatan dan kelurahan yang belum mencapai target. Kelurahan Cihapit dan Kelurahan Merdeka merupakan dua diantara 151 kelurahan yang ada di Kota Bandung yang telah melaksanakan PIPPK. Kelurahan Cihapit berada dibawah wilayah Kecamatan Bandung Wetan sedangkan Kelurahan Merdeka berada dibawah wilayah Kecamatan Sumur Bandung. Kedua kelurahan tersebut jaraknya cukup berdekatan dan berada di pusat perkotaan dengan karakteristik penduduk yang mayoritas bermata pencaharian karyawan atau wirausahawan.

Kelurahan Cihapit memiliki luas wilayah 123 Ha dan jumlah penduduk 6.272. Jumlah Kepala Keluarga di Kelurahan Cihapit saat ini mencapai sekitar 1.040 KK dan KK miskin sebanyak 75 KK berdasarkan data Kependudukan Kelurahan Cihapit per Desember tahun 2015. Sedangkan Kelurahan Merdeka 140 Ha dengan jumlah penduduk 9.284 jiwa. Jumlah Kepala Keluarga di Kelurahan Merdeka saat ini mencapai sekitar 2.777 KK dan KK miskin sebanyak 110 KK berdasarkan data Kependudukan Kelurahan Merdeka pada tahun 2015.

Menurut hasil rekapitulasi serapan anggaran PIPPK 2015 Kelurahan Merdeka hanya mencapai 83,19\% termasuk kedalam kelurahan terendah dalam penyerapan realisasi anggaran PIPPK tahun 2015 sedangkan untuk Kelurahan Cihapit realisasi pada tahun 2015 dan 2016 mencapai 100\%. Sedangkan untuk realisasi anggaran PIPPK tahun 2016 Kelurahan Cihapit realisasi anggarannya sudah mencapai 95,50\% dan untuk Kelurahan Merdeka Realisasi anggarannya naik mencapai 84,20\%.

Kelurahan Cihapit merupakan satu-satunya kelurahan yang berada di 
pusat perkotaan Kota Bandung yang hasil realisasi anggarannya termasuk yang cukup tinggi diantara kelurahan lainnya. Menurut wawancara pra observasi penulis dengan pegawai pemerintahan umum, bahwa memang di wilayah yang letaknya di pusat kota respons masyarakat terhadap Program Inovasi Pembangunan dan Pemberdayaan Kewilayahan (PIPPK) belum optimal, bergantung pada aparat kewilayahannya apakah bisa mengkoordinir masyarakatnya atau tidak, yang menjadi istimewa walaupun Kelurahan Cihapit letaknya ada di pusat perkotaan tetapi dalam kegiatan PIPPK realisasi anggaran Kelurahan Cihapit termasuk ke dalam Kelurahan yang terbaik.

Begitupun kegiatan-kegiatan yang dilakukan, realisasi anggaran bisa maksimal dikarenakan adanya peran aparat kewilayahan yang sangat sinergis dengan warga masyarakatnya sehingga masyarakat pun terutama empat lembaga kemasyarakatan RW, PKK, LPM dan Karang Taruna ikut berperan dalam mengkoordinir kebutuhan masyarakat. Berikut ini adalah daftar perbaikan infrastruktur tahun 2015 di Kelurahan Cihapit Kecamatan Bandung Wetan.

Dapat kita lihat pada data di Kelurahan Cihapit tahun 2015 menunjukkan urutan infrastruktur yang dibangun melalui dana PIPPK mulai dari RW 01 hingga RW 08 di Kelurahan Cihapit Tahun 2015. Setiap RW mendapatkan perbaikan infrastruktur diantaranya perbaikan pos ronda, gorong-gorong atau saluran air, pemeliharaan taman lingkungan dan perbaikan kantor RW. Program dapat kita lihat dalam kegiatan PIPPK pada LPM, Karang Taruna, dan PKK lebih menitikberatkan pada kegiatan-kegiatan sosialisasi serta pelatihan-pelatihan yang melibatkan narasumber atau tenaga ahli dan kegiatan-kegiatan partisipasi masyarakat terhadap acara-acara yang ada di Kota Bandung seperti hari jadi Kota Bandung dan HUT RI.

Begitupun data yang ada di kelurahan Merdeka Kecamatan Sumur Bandung, perbaikan infrastruktur dititik beratkan pada pemeliharaan gedung seperti poskamling, balai serbaguna, gapura dan perbaikan saluran air/gorong-gorong yang merupakan perbaikan infrastruktur dari dana PIPPK. 
kegiatan lembaga kemasyarakatan LPM, Karang Taruna, dan PKK untuk tahun 2015 di Kelurahan Merdeka lebih banyak digunakan untuk belanja modal seperti pembelian computer, Belanja Modal Peralatan dan Mesin - Pengadaan Alat Kantor (Belanja meja Kantor, rak, Kursi), daripada dialokasikan untuk kegiatan seperti di Kelurahan Cihapit.

Tolak ukur keberhasilan PIPPK dilihat selama ini dari sejauh mana anggaran yang diberikan oleh Pemerintah Kota Bandung dapat terserap secara maksimal oleh setiap Kelurahan sebagai Kuasa Pengguna Anggaran (KPA). Dengan melihat tolak ukur di atas Kelurahan Merdeka tentunya lebih bisa memaksimalkan potensi yang ada di wilayahnya daripada Kelurahan Cihapit , mulai dari luas wilayahnya yang lebih besar, hingga jumlah penduduknya yang lebih banyak dibandingkan dengan Kelurahan Cihapit. Berdasarkan hasil wawancara pra observasi dengan Lurah Cihapit, Lurah Merdeka, dan pegawai Bagian Pemerintahan Umum Pemerintah Kota Bandung terdapat beberapa indikasi masalah evaluasi program yaitu Pencairan dana PIPPK terlambat dilakukan yang seharusnya sudah cair pada bulan maret 2015 dikarenakan adanya kendala di dalam aturan perwal maka dana tersebut baru cair pada bulan agustus 2015 sedangkan kegiatan harus rampung bulan desember 2015 dan dana PIPPK harus terserap oleh semua lembaga kemasyarakatan, hal tersebut menimbulkan banyak tumpang tindih kebutuhan yang tidak sesuai dengan kebutuhan masyarakat, Sebagian besar masyarakat masih memiliki pemahaman dana 100 juta rupiah berupa uang tunai seperti dana hibah bukan berupa program kegiatan, Pemerintah Kota belum mempersiapkan dukungan Sumber daya manusia khususnya aparat dikewilayahan secara optimal sehingga mempengaruhi gerak operasional dalam pelaksanaan program, Ada kecenderungan justru dengan adanya PIPPK ini masyarakat menjadi membebankan semua kegiatan pada dana PIPPK padahal pemerintah Kota Bandung pada awal munculnya program ini bertujuan untuk menstimulasi partisipasi masyarakat dalam pembangunan yang ada dikewilayahan dan Evaluasi program belum fokus pada capaian program, kemudian evaluasi yang 
dilakukan cenderung bersifat formatif dan hanya menekankan pada aspekaspek administrasi keuangan, sebagai akibat belum fokusnya evaluasi program maka evaluasi yang dilakukan selama ini tidak dapat menangkap kondisi para penerima atau manfaat dari masing-masing Program Pembangunan dan Pemberdayaan Kewilayahan (PIPPK)

Agar dapat mengetahui sejauh mana tingkat efektivitas capaian sasaran serta sejauh mana kondisi penerima dan pemanfaat dari PIPPK bukan hanya ditinjau dari segi penyajian data-data keberhasilan yang diukur dari tingkat partisipasi atau keikutsertaan masyarakat dan keberhasilan realisasi anggaran program yang dilihat dari segi kuantitasnya untuk itu diperlukannya suatu analisis yaitu berupa kajian berdasarkan Analisis program dalam mengkaji lebih dalam indikasi - indikasi yang sudah dibahas di atas. dan penulis ingin melihat mengapa PIPPK ini bisa lebih berhasil di jalankan di Kelurahan Cihapit dibandingkan dengan Kelurahan Merdeka yang keduanya sama-sama berada di pusat perkotaan dan menggunakan SOP yang sama yaitu perwal No.346 Tahun 2015 Tentang Juknis PIPPK.

Berbagai kajian terhadap penelitian terdahulu yang telah dilakukan (Komigi, 2015), (Rd. Moh. Darajatun, 2016), (Suaib Djafar, 2013) dan (John Yus Madoli, 2013) terdapat perbedaan dari tema, lokus dan fokus penelitiannya pun berbeda sedangkan persamaan dari ketiga peneliti terdahulu dan penulis yaitu kesamaan dalam mengkaji mengenai evaluasi kebijakan/program dimana langsung mengevaluasi pada program atau kebijakannya bukan pada evaluator menggunakan dasar teori dari beberapa ahli, dengan harapan gambaran pengelolaan PIPPK menjadi lebih variatif dengan analisis yang lebih komprehensif.

\section{METODE PENELITIAN}

Dalam penelitian ini peneliti menggunakan pendekatan kualitatif deskriptif yaitu dengan menggambarkan hasil yang peneliti dapat dari lapangan baik itu dari observasi,studi pustaka maupun wawancara dengan melihat dari konteks kegiatan dan pelaksanaan di lapangan (Darmawan, 2013). Teknik analisis data yang digunakan oleh peneliti yaitu dengan 
mengikuti model interaktif, dimana komponen-komponen analisis data (reduksi, penyajian data, penarikan kesimpulan) secara interaktif saling berhubungan selama dan sesudah pengumpulan dan menerjemahkan data kasar dilanjutkan dengan penarikan kesimpulan dan diuji dengan teknik Triangulasi (Rahardjo, 2010).

\section{HASIL DAN PEMBAHASAN}

Mencakup analisis masalah yang berkenaan dengan lingkungan program atau kondisi objektif yang akan dilaksanakan. Berisi tentang kekuatan dan kelemahan objek tertentu. konteks sebagai focus institusi yang mengidentifikasi peluang dan menilai kebutuhan. Suatu kebutuhan dirumuskan sebagai suatu kesenjangan (discrepancy view) kondisi nyata (Reality) dengan kondisi yang diharapkan (Ideality). Dengan kata lain konteks berhubungan dengan analisis masalah kekuatan dan kelemahan dari objek tertentu yang akan atau sedang berjalan. konteks memberikan informasi bagi pengambil keputusan dalam perencanaan suatu program yang akan dilaksanakan. Selain itu, konteks juga bermaksud bagaimana rasionalnya suatu program. Analisis ini akan membantu dalam merencanakan keputusan, menetapkan kebutuhan dan merumuskan tujuan program secara lebih terarah dan demokratis. Evaluasi konteks juga mendiagnostik suatu kebutuhan yang selayaknya tersedia sehingga tidak menimbulkan kerugian panjang. Dengan terus menerus mengadakan sosialisasi yang aktif dengan warga terutama dibantu oleh empat lembaga kemasyarakatan pendekatan yang dilakukan oleh Tim Pengarah Pelaksana PIPPK Kelurahan Cihapit cukup efektif untuk menggugah kesadaran warganya akan pentingnya program ini yaitu untuk menstimulasi partisipasi seluruh lapisan warga masyarakat untuk ikut terlibat dalam program pembangunan dan pemberdayaan yang dimulai dari skala kewilayahan dengan tujuan utamanya adalah pemerataan pembangunan khususnya di Kota Bandung.

Kelurahan Merdeka merupakan salah satu Kelurahan yang masih kurang dalam penyerapan anggarannya, ada beberapa hal yang membuat penyerapan anggaran di kelurahan merdeka kurang salah satunya karena 
kekurangan aparatur yang membuat sosialisasi kepada masyarakat menjadi kurang, kelurahan merdeka terletak di salah satu daerah yang cukup dekat dengan pemukiman kota Bandung dimana terletak daerah dengan pemukiman Militer, hal ini membuat anggaran semakin tidak terserap karena dalam pemukiman itu sendiri pihak militer juga sudah menganggarkan untuk perbaikan lingkungan sekitar, kelurahan merdeka memiliki 9 RW yang dapat kita lihat pada Gambar 1.

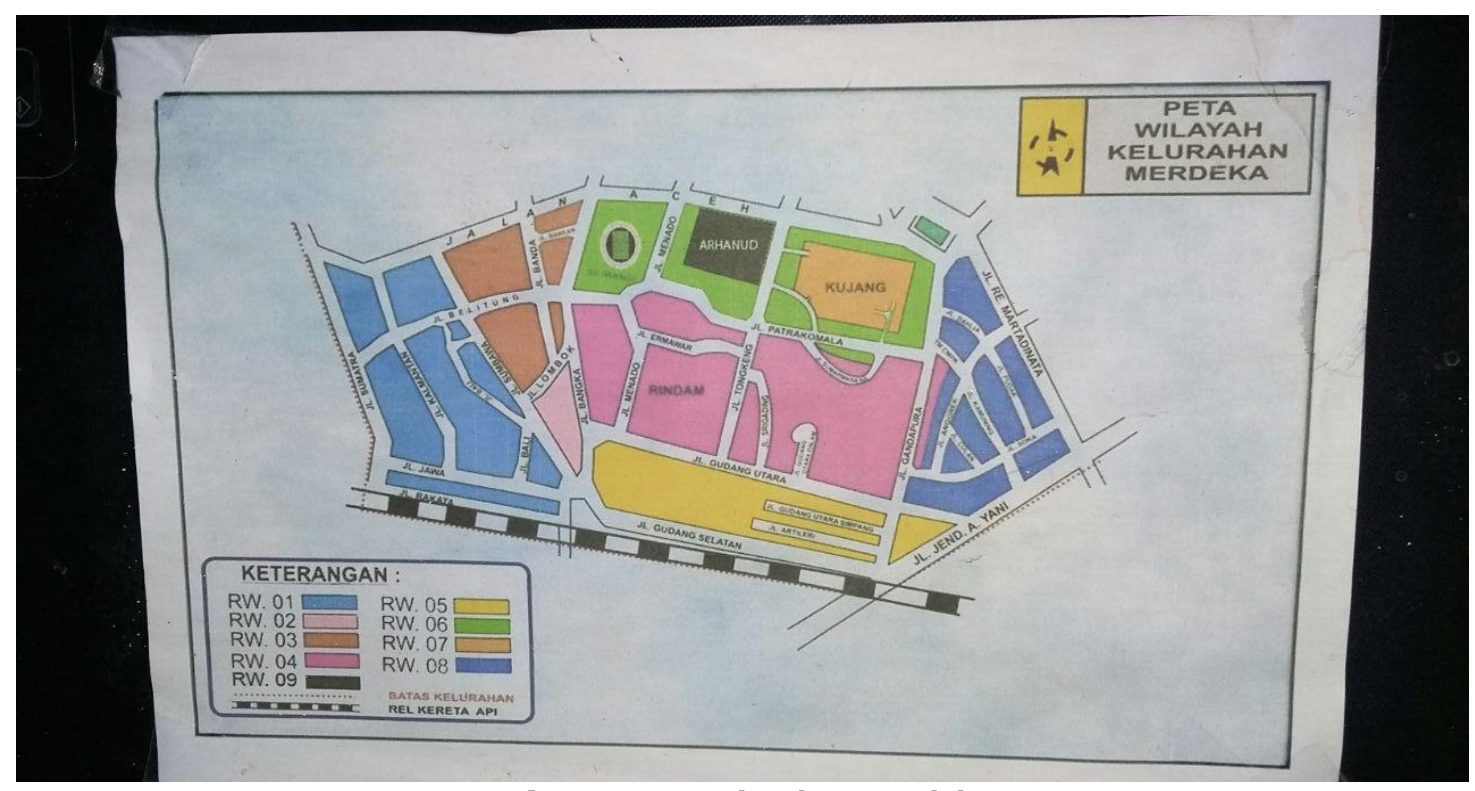

Gambar 1. Peta Kelurahan Merdeka

Sumber: Dokumentasi Penulis, 2017

Lingkungan Kelurahan Merdeka yang sebagian besar penduduknya dan wilayahnya dikuasai oleh TNI justru menjadi hambatan yang cukup menjadi tantangan tersendiri bagi Kelurahan merdeka untuk menjalankan program yang digulirkan oleh Pemerintah Kota Bandung ini. Lalu informasi lainnya yang ditemukan oleh peneliti dari informan 8 dan 9 yaitu Ketua Paguyuban RW dan Ketua LPM Kelurahan Merdeka hambatan lain yang ditemukan selain dari masyarakat yang berprofesi sebagai anggota TNI adalah juga datang dari masyarakat menengah kebawah yang seharusnya antusias pada program PIPPK ini justru mereka juga ikut acuh tak acuh, hal ini bisa terlihat di pada RW 05 yang meliputi wilayah Jalan Gudang Utara dan Selatan pada bagian belakang jalan tersebut terdapat penduduk yang tinggal di pinggiran rel kereta api. Menurut pengakuan informan tersebut penduduk di wilayah RW 05 sebagian besar kurang antusias karena mereka lebih beranggapan 
menginginkan adanya bantuan langsung tunai berupa uang daripada program atau kegiatan seperti pelatihan, diadakan pelatihan pun tidak ada yang berkelanjutan seperti misalnya pelatihan pembuatan kerajinan tangan, menjahit, tata boga maupun urban farming yang diselenggarakan dari PIPPK.

Adanya persepsi sebagian masyarakat yang menganggap bahwa PIPPK ini bukan program yang penting merupakan lingkungan kebijakan yang dapat mempengaruhi kinerja dimana lingkungan kebijakan merupakan faktor yang dinamis yang merupakan salah satu unsur dari sistem kebijakan publik dan berperan dalam proses kebijakan (Lubis, 2009). dan juga pada Kelurahan Merdeka ada permasalahan yaitu ada beberapa Kasi yang akan pensiun yang mengakibatkan terjadinya penumpukan pekerjaan kepada satu orang Kasi sehingga membawa efek kurang baik ke dalam pengimplementasian PIPPK yaitu kurangnya komunikasi antara implementator dan fasilitator yang menyebabkan kurang maksimalnya pendampingan kepada masyarakat daerah Kelurahan Merdeka.

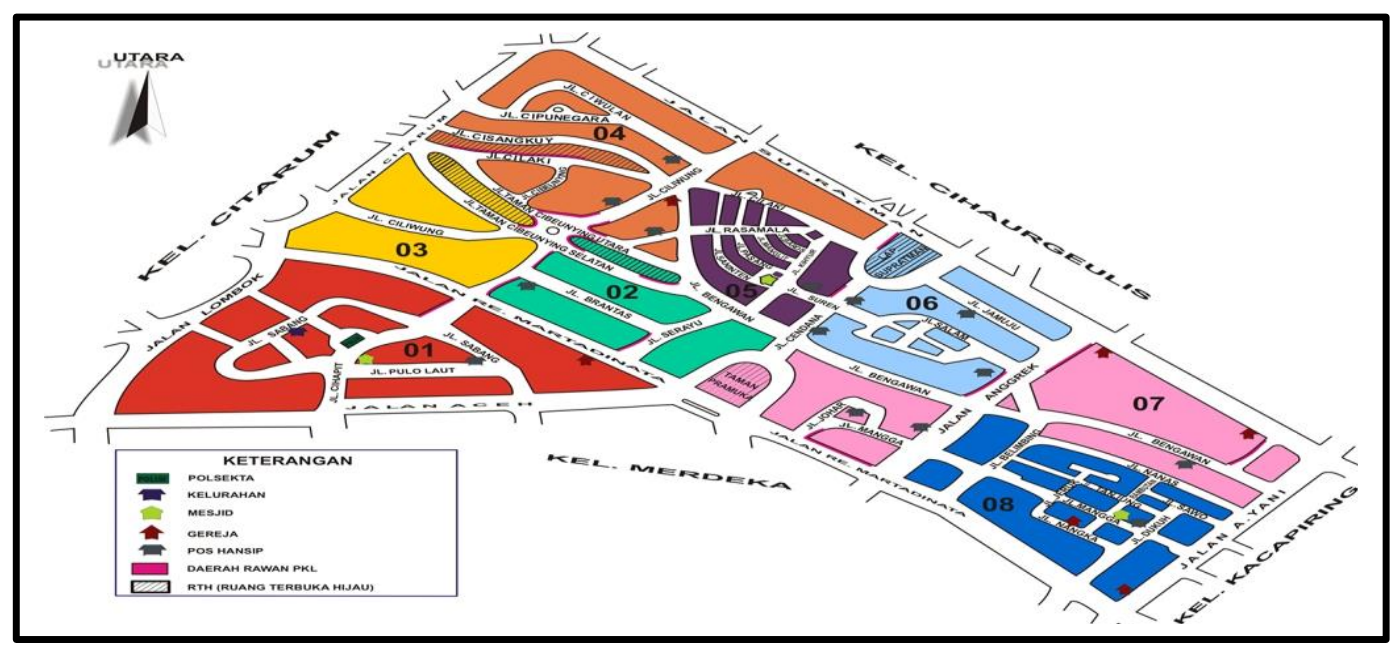

Gambar 2. Peta Kelurahan Cihapit

Sumber: Monografi Kelurahan Cihapit 2015

Dapat kita lihat pada peta diatas wilayah kelurahan cihapit dibatasi oleh bagian selatan: Kelurahan Kacapiring Kecamatan Batununggal, bagian utara: Kelurahan Citarum Kecamatan Bandung Wetan, bagian timur: Kelurahan Merdeka Kecamatan Sumur Bandung, bagian barat: Kelurahan Cihaur Geulis Kecamatan Cibeunying Kaler. RW 01 terdiri dari wilayah Jalan Lombok, Jalan Sabang, Jalan Pulo Laut, Jalan Cihapit, dan Jalan Martadinata. RW 02 terdiri dari Jalan Brantas, Jalan Serayu, Jalan Bengawan dan Sebagian 
Jalan Taman Cibeunying Utara dan Selatan dan Jalan Martadinata. RW 03 terdiri dari Jalan Ciliwung, Jalan Citarum, Jalan martadinata, dan sebagian Jalan Taman Cibeunying Selatan dan Utara. RW 04 terdiri dari Jalan Ciliwung, Jalan Cisangkuy, Jalan Cipunegara, Jalan Cimanuk, Jalan Supratman, dan Jalan Ciwulan. RW 05 terdiri dari Jalan Rasamala, Jalan Cilaki, Jalan Saninten, Jalan Manglit, dan Jalan Baros. RW 06 meliputi wilayah Jalan Cendana, Jalan Salam, Jalan Jamuju, Jalan Salam, dan Lapangan Supratman. RW 07 terdiri dari Jalan Bengawan dan Jalan Anggrek. Sedangkan yang terakhir RW 08 Jalan Nanas, Jalan Mangga, Jalan Sawo, Jalan Dukuh, Jalan Jeruk, Jalan Tanjung, Jalan Rambutan, dan Jalan Belimbing.

Kelurahan Cihapit dan Merdeka dalam pelaksanaan PIPPK telah melakukan sosialisasi yang intensif ditunjukkan dengan mengajak secara Bersama RW, RT, PKK dan karang taruna melalui Musrembang hanya saja terdapat perbedaan penyusunan program kerja dari kedua kelurahan dan juga aparatur dan masyarakat di desa Cihapit lebih terdorong untuk mengikuti kegiatan PIPPK sehingga anggaran di Desa Cihapit dapat diserap secara maksimal.

\section{SIMPULAN}

Upaya penggerakan masyarakat dapat terwujud apabila semua lintas program dan lintas sektor serta masyarakat memahami tanggung jawab, tugas dan fungsinya. Untuk itu diperlukan peningkatan pemahaman, pengetahuan dan kemampuan lintas sektor/lintas program serta masyarakat, kegiatan pembinaan kader PKK, LPM dan Karang Taruna menjadi wahana yang menjembatani antara kebutuhan program dan proses kemandirian masyarakat. Dalam pemberdayaan masyarakat yang terpenting adalah bagaimana menjadikan masyarakat pada posisi pelaku pembangunan yang aktif dan bukan penerima pasif oleh karena itu salah satu penyebab kurangnya penyerapan anggaran kelurahan merdeka dibanding dengan kelurahan cihapit dan diperlukannya diseminasi(Akib, 2012) yang dilakukan dengan baik. 


\section{DAFTAR PUSTAKA}

Akib, H. (2012). Implementasi Kebijakan: Apa, Mengapa Dan Bagaimana. Jurnal Ilmiah Ilmu Administrasi Publik, 1(1), 1-11.

Darmawan, D. (2013). Metode Penelitian Kuantitatif. Bandung: Pt Remaja Rosdakarya.

John Yus Madoli. (2013). Evaluasi Kebijakan Penyelenggaraan Ketertiban Umum Di Kabupaten Poso (Studi Penegakan Peraturan Daerah Oleh Satuan Polisi Pamong Praja Di Kabupaten Poso).

Komigi, I. (2015). Evaluasi Program Nasional Pemberdayaan Masyarakat (Pnpm) Mandiri Perdesaan Di Kabupaten Sorong Provinsi Papua Barat (Studi Kasus Pada Suku Moi).

Lubis, A. (2009). Upaya Meningkatkan Partisipasi Masyarakat Dalam Pembangunan. Jurnal Tabularasa, 6(2), 181-190.

Pitriyanti, D., \& Harsasto, P. (2019). Kepemimpinan Ridwan Kamil Di Koa Bandung Tahun 2013-2018: Kajian Inovasi Kebijakan Kepemimpinan Adaptif. Journal Of Politic And Government Studies, 8(02), 101-110.

Rahardjo, M. (2010). Triangulasi Dalam Penelitian Kualitatif.

Ramdani, D. F., \& Habibi, F. (2017a). Penguatan Partisipasi Masyarakat Dalam Mendorong Program Smart City Di Kota Bandung. Prosiding Seminar Nasional Riset Terapan / Senasset, O(0), 125-129. Retrieved From Http://E-

Jurnal.Lppmunsera.Org/Index.Php/Senasset/Article/View/436/462

Ramdani, D. F., \& Habibi, F. (2017b). Penguatan Partisipasi Masyarakat Dalam Mendorong Program Smart City Di Kota Bandung. Prosiding Seminar Nasional Riset Terapan/ Senasset, 125-129.

Rd. Moh. Darajatun. (2016). Evaluasi Kebijakan Kewenangan Badan Koordinasi Pemerintahan Dan Pembangunan (Bkpp) Wilayah Iv Provinsi Jawa Barat.

Suaib Djafar. (2013). Evaluassi Kebijakan Pemngambangan Pariwisata Pulau Togian Kabupaten Tojo Una Una Provinsi Sulawesi Tengah.

\section{Perundang-Undangan Dan Dokumen Lainnya}

1. Kecamatan Bandung Wetan Dalam Angka 2015

2. Kecamatan Sumur Bandung Dalam Angka 2015 
POLITICON : Jurnal Ilmu Politik Vol.1 No.2 ; Hal 193-204

Website : http://journal.uinsgd.ac.id/index.php/politicon ISSN : 2685-6670 ( Online )

3. Keputusan Walikota Bandung Nomor 800/Kep. 272-Bag. Pemum/2016 Tentan Tim Pengarah Pelakasanaan Program Inovasi Pembangunan Dan Pemberdayaan Kewilayahan (Pippk) Kota Bandung Tahun 2015

4. Monografi Kelurahan Cihapit Tahun 2015

5. Monografi Kelurahan Merdeka 2015

6. Peraturan Daerah Kota Bandung Nomor 3 Tahun 2014 Tentang Rencana Pembangunan Jangka Menengah Daerah (Rpjmd) Tahun 2014-2018

7. Peraturan Walikota Nomor 436 Tahun 2015 Tentang Pelaksanaan Program Inovasi Pembangunan Dan Pemberdayaan Kewilayahan Yang Selanjutnya Disingkat Pippk.

8. Undang-Undang Nomor 23 Tahun 2014 Tentang Pemerintah Daerah 